Riga Teacher Training and Educational Management Academy, University of Latvia, Latvia

\title{
Grammatical Functions of Verbs in Child Language
}

\section{Abstract}

The article explores the division of grammatical functions of verbs that, according to the author, is the most suitable for the general Latvian language system and illustrates this division with practical examples of language use. Respectively, all verbs are divided into two groups according to their grammatical functions - independent verbs and auxiliary verbs. All groups of verbs used with an auxiliary meaning are explored - auxiliary verbs, copulas and modal verbs. This division of verbs is based on the grammaticalization of the verbs, since, formerly, verbs, now used in auxiliary sense, were used in a substantive meaning and only gradually acquired their auxiliary meaning.

The use of auxiliary verbs is a significant indicator of a grammatical system development of a language, therefore it also attracts the attention of child language researchers, as it allows exploring in what order and in what ways children acquire the corresponding meanings and functions of verbs. The aim of this study is to, within limitations, explore the grammatical functions of verbs used in child language and the order of their acquisition, to analyze peculiar constructions that are formed with auxiliary verbs, as well as to detect problems that should be prevented prior to further research. One of the main problems is the limited child language material available for this study. In order to objectively judge about the ways the grammatical system develops in child language, one should first conduct full research on language of several children, as this is the only way to observe the order and ways in which certain forms and constructions emerge in child language.

Child language has the same division of grammatical functions of verbs as general language. By studying the acquisition sequence of various grammatical functions in child language, it may be concluded that independent verbs are the first to appear in child language. Children start using auxiliary verbs later - initially they use the verbs with an auxiliary meaning that are the most common in the language of their parents and in the most common constructions. The order of their appearance is as follows: copula būt (to be), modifiers gribēt, varēt (want, can), auxiliary verb būt (to be) (initially present perfect forms of the indicative mood, the rest of the forms emerge significantly later). Constructions with auxiliary verbs that are not characteristic to general language are also common in child language. Such constructions are formed at the beginning stages of auxiliary verb application, before the grammatical function system of verbs is fully understood.

Key words: auxiliary verb, copula, modal verb, child language. 


\section{Introduction}

It is largely believed that in the process of word acquisition children first start using nouns and only then verbs. The commonly held belief is that learning of verbs is difficult. (See for example Maguire, Hirsh-Pasek, Golinkoff 2006, 364-365.) However certain processes in child language are just as meaningful as objects, therefore words signifying a process may appear in a child's language quite early, soon after the first nouns. Initially it is difficult to distinguish between a word being used with the significance of a noun or a verb. Yet it is safe to say that the first verbs that signify an activity are used in their independent meaning and these are the most commonly used verbs in a child's language environment. As a child's language develops, there gradually begin to appear different forms of verbs.

The peculiarities most clearly detected in research on verbs in child language are just these unusual forms of verbs or a peculiar way of making the forms (for example, the paradigm būt (to be): iru 'esmu', iri 'esi', iram 'esam', irat 'esat', Freidenfelds et al. 32; pasakt 'pasacīt', es sakšu 'pasacī̌̌u', Freidenfelds et al. 70), just like formation of words - new lexical and morphological formations (jüroties 'peldēties', Freidenfelds et al. 34; karsināt 'karsēt', Freidenfelds et al. 36; mūma 'govs', Freidenfelds et al. 52), semantic changes (Dzenis izgrauza 'izkala' caurumu, Freidenfelds et al. 32) and phonetic changes (gibèt, glibēt 'gribèt', Freidenfelds et al. 29; nebās 'negribas', Freidenfelds et al. 54; tadïjās 'gadijjās', Freidenfelds et al. 76). Yet all of these are traits characteristic to the language of children in general and they largely concern all the other parts of speech.

This time the grammatical functions of verbs, and of auxiliary verbs in particular, will be explored closer. Due to the limited number of language materials these peculiarities are somewhat more difficult to distinguish, yet they should be considered and are even more significant from the point of view of language system acquisition.

\section{Aim of the study}

Child language in Latvian linguistics has little been studied in this aspect, yet it may provide new insights into the development of a child's language and thinking, as well as provide a significant understanding of the development of grammar as such. The course of the study sketches issues that are encountered in studies of this kind and which for now are of significance to Latvian linguistics. Respectively, the aim of the study is to, within limits of the study, explore the grammatical functions of verbs encountered in child language as well as the sequence of their appearance by analyzing peculiar constructions of auxiliary verbs and to detect issues to be solved prior to further research. 


\section{Materials and methods}

The article explores theoretical literature on grammatical functions of verbs, and it lists and analyzes language examples. Two types of practical language material are used: 1) adult language examples (taken from the Balanced contemporary Latvian language text corpus "miljons-2.0"), see www.korpuss.lv; examples in the text are marked with an abbreviation " $\mathrm{K}$ ") for detection of grammatical functions of verbs in general language; 2) child language examples (sources: I. J. Freidenfelds, D. Lapāne, D. Markus "Bērnu valodas vārdnīca" ("The Dictionary for Child Language")(2009); RTTEMA Child Language Research Centre children's language database "Jēdzienu interpretācija bērnu zīmējumos" ("Interpretation of Concepts in Children's Drawings"); D. Markus "Bērna valoda: no pirmā kliedziena līdz pasakai" ("Child Language: From the First Cry to a Story")(2003); D. Markus "Bērns runā kultūras pasaulē" ("A Child Speaks in the World of Culture")(2005); V. RūḳeDraviņa "Latviešu meitene apgūst savu pirmo valodu" ("A Latvian Girl Learns Her First Language") (1993), as well as several observations of the author, self-detected examples). In line with the aims of the study theoretical notions in literature are analyzed, language examples are excerpted and analyzed.

\section{Results and conclusions}

In order to tackle grammatical functions of verbs in child language, they must first be explored in general language.

According to the syntactical functions, verbs can be divided into independent verbs (dziedāt, redzèt, snigt (to sing, to see, to snow) etc.) and verbs with an auxiliary meaning, i.e., auxiliary verbs (būt, tikt, tapt (to be, to get, to become)), copulas (büt, tikt, tapt, klūt, škist (to be, to get, to, come to be, to seem) etc.) and modal verbs (varèt, vajadzēt, gribēt, beigt, laimēties (can, need, want, stop, get lucky) etc.). Auxiliary words traditionally are those verbs, which are used for the making of analytical forms of independent verbs, yet all copula function verbs and modal verbs also have the auxiliary meaning.

Independent verbs in the finite form when alone in a sentence function as predicates (birds sing), but auxiliary verbs form the predicate together with an independent word - auxiliary verbs with an independent verb in a participle form (Putni bija dziedajjuši visu vasaru (The birds had sung all summer)), copulas with a nominal or adverb (Vasara būs karsta; Dziedāt ir spēcinoši (the summer will be hot; singing is empowering)), modifiers with an independent verb infinitive (Es ari gribu dziedät (I, too, want to sing)). In order for the nominal part of the predicate - the nominal, the pronoun, the conjugated participle -, as well as the infinitive and the adverb to function as a predicate, it is needed to have an element that creates the grammatical meanings characteristic to the predicate (respectively, to the independent verb) - person, time, expression and voice. Thus there are independent 
verbs, which initially performed the predicate function by themselves, yet in such predicate constructions, through partial desemanticization now become the unifying element - acquire an auxiliary meaning and express the majority of grammatical meanings of a predicate, by leaving the expression of lexical meaning largely to the remaining part of the predicate.

Such a division of verbs is based on the grammaticalization process of verbs, respectively, gradual transition of lexical units into grammatical ones, with disappearing or simplification of the semantics, syntactic autonomy, morphological structure, phonetic contents of the linguistic element. For example, through grammaticalization the syntactic construction may become a word form, a lexical unit may become an auxiliary word, and an auxiliary word may become an affix (Trask 2000, 141; Kalnača 2005, 125; VPSV 2007, 133). The above-mentioned separate groups of words are verbs that exist in various levels of grammaticalization, besides a single verb may often exist on various different levels.

Thus an auxiliary word or an auxiliary verb is "a verb that together with a participle form of an independent verb is used for the creation of an analytical form of a verb time, type, expression or voice" (VPSV 2007, 274). Auxiliary verbs have developed through grammaticalization: independent verb > auxiliary verb. In Latvian language auxiliary verbs are büt, tikt, tapt (to be, to get, to become). For example: Pasaule sākas no tās vietas, kur esi dzimis. (The world begins in the place where you are born.) ( $\left.\mathrm{K}^{1}\right)$ Tasks meant for children, of course, will not get forgotten. (Protams, netikšot aizmirsti arī bērniem domāti darbi.) (K) Tas viss arī noved pie tā, ka pärlieku lielas laužu masas karjera krīzes laikā top nevis nobremzēta, nevis pārinstrumentēta, bet pilnigi degradeta. (All this lead to an outcome that careers of too many people during the crisis become not slower, not restructured, but totally degradated.) (K)

A copula is a "verb that performs a syntactic auxiliary function in a compound predicate and expresses its grammatical meanings - time, person, modality" (VPSV $2007,334)$. It is a verb with a weak independent lexical meaning, the main task of which is to link together other elements of sentence structure. Copulas have developed through grammaticalization: independent verb > copula (indirectly in Mìlenbahs 1898, 27; Bergmane et al. 1962, 235; Beitina 1964, 8; Valdmanis 1989, 34). In traditional Latvian linguistics copulas are considered to be verbs būt, tikt, tapt, klūt (to be, to get, to turn, to become): Esmu lïbietis, runāju lïbiski, bet mans bērns ir latvietis. (I am a Liv, I speak the Liv language, but my child is Latvian) (K) Bet, ja ari visas, kas gribēja, netika aktrises, tad tomēr netika arī tik klaji publiski izrādīts, ka darba piramidas pamata dubli vien. (Although everyone, who had wanted to, did not turn into an acress, it was not publically shown that there is only mud at the foot of the work pyramid) (K) Apmèram desmit gadus es mäcijos, kamēr man tapa skaidrs, kas Jänos ir jädara. (I have been studying for about ten years, until it became clear to me what needs to be done at Jānini) (K) Pḷāvums noteikti jāsavāc, citādi maurin,š izsutīs, kḷuss

1 " $K$ " indicates examples taken from the Balanced contemporary Latvian language text corpus "miljons-2.0", www.korpuss.lv. 
brüngans un säks pelèt. (The mowing should definitely be collected, or else the lawn will foment, become brown and start to grow moldy. (K)

However other verbs are also frequently being used as copulas (in Latvian linguistics these are traditionally called copula verbs ${ }^{2}$ ). These have three meanings:

1) The meaning of having a certain characteristic or trait (büt - gadìties, atgadìties, sagadìties, justies, sajusties, klāties, iznākt, nākties, izrādīties, turēties, noturēties, pieturēties, palikt, izdoties, padoties, stāvèt etc. (to be - to happen, to occur, to coincide, to feel, to experience, to get on, to be off, to appear, to manage, to keep, to endure, to hold on to, to stay, to succeed, to give up, to stand etc.): Un pat tad, ja abi esat gadijjušies tādi mierīgi un nosvērti, .. sirds nav brīva. (And even if both of you happen to be so calm and balanced, .. the heart is not free.) (K) Bez veiksmes vienmér kläjas grūti. (Without luck it is always difficult to get on) (K) Auns gan esot padevies nīkulīgs, bet melngalvju škirne pati par sevi ir laba. (The ram has managed to be puny, but the Blackhead breed itself is good) (K) Malkas škūnis stäv tukšs. (The wood shed stays empty) (K) Filiälu funkciju un uzdevumu apjoms paliks nemainigs. (The volume of functions and tasks of the branches will remain the same.) (K)

2) The meaning of a change in the situation or of a trait (klüt, tikt, tapt (to become, to get, to grow) - mesties, apmesties, atmesties, samesties, nākt, vērsties, izvērsties, palikt (rush, to settle, to fling, to turn out, to come, to move on, to develop, to remain): (Both games turned out nearly similar) (K) Cep aptuveni 6-8 minūtes, kamèr malas paliek brūnas. (Bake it for approximately 6-8 minutes until the edges turn brown (K)

3) The meaning of an appearance (škist, škisties, likties, izlikties, izskatīties, skaitities, sacities (to appear, to seem, to look to be, to pretend, to look, to count, to claim)): Tas, kas reiz šksita tāls, pēkšn, ir tuvs. (That, which once seemed distant, all of a sudden is close.) (K) Ugunskura gaismā gaiši zilä kräsa liksies zalı, baltā-dzeltena un violeta - brūna. (In the light of the campfire the light blue color will appear green, the white will appear yellow and the violet - brown) (K) Pašlaik, ziedēšanas laikā, astilbju dobe izskatäs patiešäm krāšna. (Now during the bloom time the bed of astilbes looks really gorgeous) (K) Man vēl jānoskaidro, kā isti jāpiebūvē otra èka, lai tā skaitītos atsevišk, büve. (I still need to find out how to build an outbuilding for it to count as a separate construction) (K) (Kārklinš 1974, 44-49; Freimane 1985, 56).

2 By observing the distinciton between copulas and copula verbs, the grammaticalization process should be depicted as follows: independent verb > copula verb > copula, respectively, copulas have almost fully desemanticized, while copula verbs have only partly semanicized. They have a lexical meaning, which is more pronounced than that of the copulas, and they are also used as independent verbs more frequently than copulas (except for to be). Therefore copulas only link together the structural elements of a sentence, while copula verbs also give the predicate a significant nuance of meaning. The verb to be has grammaticalized in just the same way: büt 'augt, kuplot, elpot, mist, stāvēt utt.' (vin,š bija 'vin,š auga') > būt 'augt utt.' (vin,š bija liels 'vin,š auga, kluva liels') > būt 'būt' (vin,š bija liels) (to be, to grow, to thicken, to dwell, to stand etc.' (he was 'he grew') >to be 'to grow etc.', (he was big 'he grew, became big')> to be 'to be' (he was big) (Mïlenbahs 1898, 25-28; Ambrazas 2006, 155-156). Yet the level of desemantization of verbs used in a copula function is difficult to determine, therefore the distinction between copulas and copula verbs is not considered to be objective. 
Modifiers (previously also called semantic modifiers - Freimane 1985, 3235; Paegle 2003, 91) are auxiliary verbs that together with the infinitive form the predicate or the principal part, by granting it a modal, phasal or coincidental significance (for example, respectively Mēs gribam strādāt; Mēs sākam strādāt; Mums izdevās pasträdāt (We want to work; We start to work; We managed to work)). (VPSV 2007,237) Modifiers have emerged through grammaticalization: independent verb $>$ modifier. By partly being desemanticized, modifiers grant a semantic nuance to an independent verb. By forming the predicate or the principle part (or other constructions), modifiers make the independent verb change formally, yet the initial grammatical meanings in the construction are not lost - they are transferred from the independent verb to the auxiliary verb. Similarly to other auxiliary verbs, modifiers express the grammatical meanings of a construction, yet the auxiliary meaning of modifiers can be characterized not only as grammatical but also as semantic. Modifiers with the meaning of a phase name actions indicated with the infinitive.

1) the beginning (mesties, nemties, sākt, atsākt, iesākt etc. (to rush, to dash, to begin, to resume, to start etc.)): Nonākot citā valstī un kultūrā, tu meties baudìt visu, ko celojums piedāvā. (By going to a different country and culture you rush to enjoy everything this trip has to offer.) (K) Taču tad pamazām tirgū säka parādìties baravikas, gailenes, beerzlapes. (Then little by little penny buns, chanterelles and russulas began to be sold in the market.) (K) Vai tā kādreiz atsäks pukstēt? (Will it resume beating again?) (K);

2) sequel, continuation (nebeigt, palikt, turpināt (to pursue, to remain, to continue) (etc.): Esmu pärliecināts, ka dzive nebeigs mani pārsteigt arī turpmāk. (I am sure that life will continue to surprise me in the future.) (K) Ja iedzivotäji paliek dzivot denacionalizētajā namā, jārēkinās, ka ìres griesti var strauji kāpt. (If citizens remain living in the denationalized buidling, they need to take account of the possibility of an increase in the rent ceiling.) (K) Vèl apmèram pusstundu turpinām vārìt uz lènas uguns (For about half an hour we continue to cook it on low heat) (K);

3) the end (beigt, mitēties, pärstät, rimties (to stop, to discontinue, to put an end to, settle) etc.): Pērn puķu audzētāji beidza maksāt aizñēmumu un pañēma jaunu. (Last year flower growers settled their debt and took out a new loan) (K) Kad bērni pārstäj fantazēt? (When do children stop dreaming?) (K).

The general groups of modal verbs:

1) Verbs that express a skill, a custom, an ability, a chance or - in the form of denial - the opposite to that (drïkstēt, ierast, jaudāt, mäcèt, mègt, pagūt, prast, spèt, varèt) (may, to be able, can, use to, manage, know etc.): L,oti daudzi no mums ieraduši nomainìt realitāti pret savām domām, iedomām un apsvērumiem.(Many of us are used to changing the reality into own thoughts, fantasies and considerations) (K) Atceros, kā bērnībà mèdzu blèdîties, speèlejot akläs vistinas. (When I was a child, I remember, how I used to cheat while playing the blind man's buff.) (K) Lai cilvēks 
spētu kaut ko radìt, vinam ir jāmäk ieklausîties klusumā un ieiet savā iekšèjā telpā. (In order for a person to be able to show something, he or she must know how to listen into the silence and how to enter own inner space.) (K)

2) Verbs that express intention, will, desire, preparation (apnemties, censties, gatavoties, grasīties, gribēt, gribēties, mègināt, tīkot, uzdrošināties, vēlèties u. c.) (to undertake, to intend, to, to try, to prepare, want, to covet, to dare, to wish etc.): Cilvēki paši apnēemās kopt apkārtni. (People themselves undertook to take care of the surroundings.) (K) Centämies noklūt uz pareizā celala, bet pēc vairāku stundu braukšanas atkal iestigäm. (We tried to get on the right track, but we got stuck again after driving around for several hours.)(K) Vina grib noskaidrot istenibas teoriju, kas atrodas starp faktiem un dzivajām atminām. (She wants to clarify the theory of reality, which exists in between facts and live memories.) (K)

3) Verbs that express reluctance, aversion, hesitation, avoidance (baidities, dergties, kaunēties, kautrēties, kavēties, riebties, vairīties, vilcināties etc.) (To dread, to detest, to scruple, to recoil, to avoid, to linger): Parasti pircēji baidās šos produktus pirkt, jo nezina, kā tos pagatavot. (Customers are usually afraid to buy these products, because they do now know hot to prepare them.) (K) Viens no viriešiem atzinies, ka sabiedriba kautrejjas nosaukt savu nodarbošanos. (One of the men admitted that he was ashamed to publically state his occupation) (K) Riebjas lasīt müžĭgo "kurš" vienkäršă "kas" vietā, adverbu verba vietā, bezgalïgos prievärdus un to lietojumu nevietā. (I hate reading "which" instead of the simple "that", an adverb instead of a verb and the continuous prepositions being misapplied.) (K)

4) Verbs that express inevitability, necessity (pieklāties, nākties, vajadzēt etc.) (to behoove, to require, to demand): Man pat nācās pielaikot bārdu un klūt par Ziemassvētku vecitit. (I even had to wear a beard and become Santa Claus) (K) Ja nebūtu makulatūras, vajadzētu nocirst 7579 kokus, lai saražotu atbilstošu papira daudzumu, lēš akcijas rïkotäji. (According to the organizors of the event, if there was no waste paper, we would need to cut down 7579 trees in order to produce the needed amount of paper.) (K)

All verbs conveying coincidence have the manifestation kind of significance (gadìties, izdoties, laimēties, träpities) (to happen, to succeed, to get lucky, to coincide etc.): Domāju, nu labi, mūsu paaudzei gadijāas piedzimt tādos laikos. (I thought, never mind, our generation happened to be born in times like these.) (K) Käpēc latviešiem izdodas vienoties tikai ekstrēmos apstäklos? (Why do Latvians succeed to unite only during difficult times?) (K) Man laimējās būt istajā vietā un istajā laikā. (I was lucky to be at the right place at the right time.) (K) (Kārkliņš 1976, 64-67; Freimane 1985, $32-35)$.

An equivalent division of grammatical functions of verbs exists in child language, especially when exploring child language without any age limitations. The auxiliary verb to be is used in the compound past and present forms of verbs, for instance: 
Laime ir tas, kas, ja, piemēram, tu esi sañēmis dāvanu vai izlūdzies balonu vecäkiem.(Happiness is when, for exapmle, you have received a gift or have begged for a balloon from your parents.) - An 8-year-old; "Jēdzieni", ID 65

Sarkangalvīte ar omi devās uz mājām pie mammas, jo ome bija kluvusi vesela un jaudāja iet Sarkangalvītei lïdzi. No tā laika vilku Sarkangalvīte vairs nebija satikusi. (Red Riding Hood and grandmother went home to her mother, as the grandmother had become fit again and was able to come along with Red Riding Hood. Since that time Red Riding Hood had not met the wolf anymore.) - A 6-year-old; Markus 2003, 106.

Copulas are also common, predominantly the copula būt (to be), and at times other copulas, such as klūt (to become):

Laime ir gimene. (Happiness is family.) - A 7-year-old; „Jēdzieni”, ID 68

Citu reizi, kad es nāku, man nav bailes, bet šoreiz ap sirdi kḷūst nelabäk. (At other times, when I come, I am not scared, but this time my heart becomes weak) - A 5-yearold; Markus 2003, 105

The most commonly used modifiers in the explored language material are can and want, and also may:

Darbs ir täda lieta, kur var nopelnît naudu. (Work is something, where you can earn money) - A 7-year-old; "Jēdzieni", ID 114

Sarkangalvìte izcepa pïrägus, maizes, salika grozā un ... nevarēja panest. (Red Riding Hood baked pies and buns, put them in a basket and... could not carry them) A 3-year-old; (Markus 2003, 85).

Es labāk zīmēšu, es negribu stāstīt. (I will draw, I do not want to talk) - A 4-yearold; Markus 2003, 89

Kad bites vāc medu, nedrīkst traucēt. (When bees collect honey, you may not bother them.) 5/6 g., (Markus 2007, 121).

The very first verbs that enter a child's language with the meaning of a verb are independent verbs, yet soon after, as sentence constructions are being formed, there also emerge auxiliary verbs (gribu dzert, tas ir suns (I want to drink, that is a dog)). Yet, according to the available language material, initially the diversity of used constructions is limited, just like the number of auxiliary verbs - the most commonly encountered auxiliary verbs are applied (or to be more precise, the verbs most common in the language of parents, grandparents and nannies) in the most common constructions: the copula būt (to be), later also klūt (to become), modifiers gribèt, varēt, drïkstēt (want, can, may) and later on the auxiliary verb büt (to be). Compound tense forms appear later, as it is possible to express approximately the same thing with more simple forms, thus in a more simple way. In constructions with modifiers the auxiliary meaning seems initially not to be felt, for instance: gribu dzert (I want to drink) and gribu sulu (I want juice). In this period of time other meanings that in adult language are expressed with constructions of auxiliary verbs, in child language are expressed with more simple constructions. 
Essentially that coincides with the view expressed in literature that in child language in general there may initially emerge immature constructions and, only as speech develops, these transfer into mature constructions characteristic to adult language, although that cannot be attributed to all language constructions. Emergence of so-called "non-grammatical" forms in separate constructions prior to adult language forms show that children learn and explore regularities rather than simply acquire expressions. The frequency of these constructions in adult speech must also be taken into account, as it has significant impact upon the emergence of such constructions in child language (Brown and Hanlon 2004).

Here we need to mention the study conducted by Roger Brown that explores the sequence of certain morphological forms and elements of construction in the speech of three English-speaking children. For instance, plural forms, regularly form simple past, irregular simple past, articles etc., including also the copula both the full and the shortened copula, respectively, the clitical and the full and the shortened auxiliary word. This study acknowledges that out of the auxiliary verbs the first to emerge in child language is the copula, yet that occurs later than some other morphological forms. The other auxiliary verbs emerge significantly earlier, of which first there emerges the full auxiliary word, clitical copula and last to emerge is the clitical auxiliary word (Brown 2004, 275). Modal verbs have unfortunately not been included in this study.

Due to the limited linguistic material available, it is difficult to conclude with certitude concerning the sequence of appearance of usage of auxiliary verbs in the language of Latvian children. However, it can be said that the last ones to appear are auxiliary verbs in perfect tenses. This is also demonstrated by Velta RūkeDraviṇas language material (Latviešu meitene apgūst savu pirmo valodu", 1993 "A Latvian girl learns her first language", 1993), where present perfect use ir (is) is first observed at the age of 2.5. (tagad ir [at]braucis pastnieks ${ }^{3}$ (the postman has now arrived) - 2 years and 6 months; tas lielais [lācītis] melno degunu ir [iz]staigäjies (that big [bear] with the big nose has been for a walk) - 2 years and 9 months; to ir Dainis zimmejis (Dainis has drawn this) - 2 years and 11 months; (Rūḳe-Dravina 1993, 39).

The use of past perfect appears later (es bi 'biju' édusi kiseli (I had eaten pudding) 3 years and 9 months, Rūkse-Draviña 1993, 40) and future perfect appears even at a later stage ([kad es pārnākšu] pasaki, kādi mani bērni 'lelles' būs bijuši ([when I arrive] tell me what 'dolls' my children would have been); vēläk vini būs norunājušies 'izrunājušies' (later on they will have spoken, 'talked through') - 4 years and 2 months; Rūke-Dravina 1993, 40). The distinction between separate verbs in indefinite tenses in the speech of the very same girl appears at the age of 2 (RükeDravina 1993, 36). However, the forms of relative and conditional moods are to be registered later than the perfect tense forms in indicative mood that is around 3-4 years of age (Rūḳe Draviña 1993, 43).

3 The instances quoted without noting the majority of phonetic peculiarities, since the rest of material does not registrate them in detail. 
Judging from other language materials, the most often used copulas and modifiers are already used before auxiliary verbs are.

Except for the verb büt (to be), other verbs rarely appear in the function of copula, yet they do so in a separate form. For instance, children-narrated fairy tales about Red Riding Hood in the book by Dace Markus: "Bērna valoda: no pirmā kliedziena līdz pasakai" ("Children's Language: From the First Cry to Story") these verbs are featured in a characteriscically changed meaning and a characteristically inherited meaning:

Meitenite raudāja, raudāja, bet tad palika prieciga. (The girl cried and cried, but then became glad) Mamma vecmämiñai nopirka kämìti, un vina palika priecīga (Mum bought grandmum a hamster and she became glad.) - A 5-year-old; (Markus 2003, 100).

Sarkangalvìte ar omi devās uz mājām pie mammas, jo ome bija kḷuvusi vesela un jaudāja iet Sarkangalvitei līdzi. (Red Riding Hood and grandmother went home to her mother, as the grandmother had become fit again and was able to come along with Red Riding Hood.). - A 6-year-old; (Markus 2003, 106).

Es aiziešu uz vecmāmiñas mājin,u, apēdīš vecmāmin, un izlikšos par vecmāmiñu. (I will go to grandmother's house, eat the grandmother and pretend to be the grandmother.) - A 7-year-old; (Markus 2003, 112).

More examples of such a usage are to be found narrrated among older children:

Viñas māte palūdza, lai Sarkangalvīte aiziet pie vecāsmammas, jo viña jutās slima un vientula. (Her mother asked Red Riding Hood to go see the granmother, since she felt ill and lonely.) - A 12-year-old; (Markus 2003, 137).

Kad vilks pamodās, vinš jutās loti izslāpis. (When the wolf woke up, it felt very thirsty.) - A 12-year-old; (Markus 2003, 138).

Sarkangalvītei metās mazliet bail, bet, lai omu uzjautrinātu, viña sacerēja dziesminu par meiteniti, kurai nebija bail. (Red Riding Hood became a little scared, but to cheer up the grandmother she made up a song about a girl who wasn't scared.) - A 12-year-old; (Markus 2003, 137).

An unusual usage of a verb in the form of a copula with characteristically changed meaning is also common:

„Kāpēc tev ir tik liels un brūns deguns?" - „Es jau tev teicu, ka man ir tik lielas iesnas, kad es škaudu, man deguns izstiepjas šausmigi garš!" - „Kāpēc tev ir tik lieli zobi?” - „Es sen neesmu neko èdusi, un mani zobi izstiepās tik gari!" ("Why do you have such a long and brown nose?" -"I already told you, I have such a runny nose, that when I sneeze, my nose stretches terribly long!" -Why do you have such big teeth?" -"I have not eaten anything and my teeth stretched this long".) - A 10-year-old; (Markus 2003, 136).

When it comes to modifiers, the situation is very similar. The most common, as noted earlier, are: want, can and may, but in several cases others are used, too, most often with a meaning of a phase. Yet, modifiers with several other meanings are also to be found: 
Un tad Sarkangalvìte sāka pukittes lasitt. (And then the Red Riding Hood began to pick flowers.) - A 3-year-old; (Markus 2003, 129).

Kad vin,i bija iznnemti ārā no vēdera, viṇi sāka atgūties. (When they had been taken out of the belly, they began to recover.) - A 7-year-old; (Markus 2003, 112).

"Laikam nāk pavasaris!" teica meitina un tad turpināja ar vilku iet kopā. ("I think the spring is coming!" said the girl and then continued to go along the wolf.) - A 3-yearold; (Markus 2003, 129).

Vilks labdienu nepadeva, bet metās aprīt vecmäminuu. (The wolf did not say hello, but rushed to eat the grandmother up.) - A 5-year-old; (Markus 2003, 102-105 ).

Sarkangalvīte ar omi devās uz mājäm pie mammas, jo ome bija kluvusi vesela un jaudäja iet Sarkangalvitei lïdzi. (The Red Riding Hood and grandmother went home to her mother, as the grandmother had become fit again and was able to accompany the Red Riding Hood.) - A 6-year-old; (Markus 2003, 106).

[..] vilks nemācēja peldèt un tāpēc noslīka. ([..] the wolf could not swim and therefore drowned. ) A 4.5-year-old; (Markus 2003, 133).

Tomēr [Sarkangalvīte] uzdrošinājās ienākt iekšā un tad saredzēja vecmāminu, gulèdamu krēslā. (Nevertheless, [The Red Riding Hood] dared to come in and noticed the grandmother, who was sleeping in the chair.) - An 8-year-old; (Markus 2003, 117).

An example must be mentioned, in which, in comparison to corresponding expressions in other cases of children's naration, in the conditional mood there is no modifier or, possibly, a copula. This example may, too, indicate that auxiliary verbs generally appear in chid language much later than simple forms of independent verbs:

"Cik tev liela mute!" - „Lai tevi labāk apēst!" (You have such a big mouth!" - "To eat you better!") - A 5-year-old; (Markus 2003, 89).

In comparison to: "Kāpēc tev ir tik lieli zobi?" - "Lai varētu apēst!" (Why are your teeth so big?" - "So I could eat you!"). - A 4-year-old; (Markus 2003, 96).

Separate attention should be paid to peculiar constructions that emerge in child language and that involve verbs used with an auxiliary meaning. Presumably, particularly in the initial stage of language learning, there are more such constructions, yet only one has come to my attention:

es gribu derēt 'es gribu, lai der' (I want to fit 'I want that it fits') - 2 years and 3 months

es gribu putru uztaisit 'es gribu, lai (tu) uztaisi putru' (I want to make porridge 'I want (you) to make porridge) - 2 years and 7 months

Both examples are observed in the language of the same girl and she actively forms such constructions following this example up to the age of 2 years and 9 months and possibly will continue doing so for a longer period of time. The examples use the modifier construction, without indicating the operator of the named action with the second verb. Thus presumably the broadening of meaning of a modifier construction has taken place in the child's perception. 
Child language has the same division of grammatical functions of verbs as general language. Specific study should be devoted to the order in which various grammatical functions enter child language. Although the child language material available for this study was limited, it can be concluded that the first to appear in children's language are independent verbs. Children start using verbs with an auxiliary meaning later, initially children use the verbs with an auxiliary meaning in their most common constructions used in the language of adults (grandparents, nannies, as well as the surrounding language environment in general). They have the following order of appearance: copula būt (to be) and modal verbs gribèt, varēt (want, can) (for now it is not safe to conclude whether it is copula or one of the modal verbs that comes first in this sequence), auxiliary verb büt (to be) (first used in indicative past perfect forms, the rest of the forms appear considerably later).

In child language it is also common to find constructions with auxiliary verbs that are not characteristic to general language and that reveal the children's creative approach in acquisition and use of the language. These constructions are created in the initial usage stage of auxiliary verbs - before the grammatical function system of verbs is fully comprehended.

It is generally concluded that in order to conduct an objective study, multiple collections of data and separate studies on children's language development would be required, similar to the edition by $V$. Rūḳe-Draviña "Latviešu meitene apgūst savu pirmo valodu" ("A Latvian Girl Learns Her First Language"). Then more safe and thorough conclusions could be drawn on the grammatical functions of verbs, as the majority of currently free to access language material has been collected differently, serving other research aims and thus does not suit such research on grammatical development.

\section{References}

1. Ambrazas, V. (2006). Lietuviu kalbos istoriné sintakse. [Historical Syntax of Lithuanian]. Vilnius: Lietuvių kalbos institutas, 612 p. (in Lithuanian).

2. Beitin,a, M. (1964). Lietvārda atkarīgie locījumi izteicējā (ar saitinuu būt). Teikuma uzbūve. [Noun verb dependent bending (the copula be)]. Rakstu krājums. Rĩga: LPSR Zinātn,u akadēmijas izdevniecība, 7 -50 p. (in Latvian).

3. Bergmane, A., Blinkena, A., Grabis, R. \& Sokols, E. (eds.) (1962). Mūsdienu latviešu literārās valodas gramatika. II. Sintakse. [Grammar of the modern Latvian literary language]. Rīga: LPSR ZA izdevniecība, 932 p. (in Latvian).

4. Brown, R. \& Hanlon, C. (2004). Derivational Complexity and Order of Acquisition in Child Speech. In: Lust, B. C. \& Foley, C. (eds.) First Language Acquisition: The Essential Readings. Blackwell Publishing, pp. 155-175.

5. Brown, R. (2004). The Order of Acquisition. In: Lust, B. C. \& Foley, C. (eds.) First Language Acquisition: The Essential Readings. Blackwell Publishing, pp. 274-278. 
6. Freidenfelds, I. J., Lapāne, D. \& Markus, D. (2009). Bērnu valodas vārdnīca. [Dictionary of Child Language]. Rīga: RPIVA Bērnu valodas pētijumu centrs, 91 p. (in Latvian).

7. Freimane, I. (1985). Vienkäršs teikums un tā paplašināšana. [A simple sentence and its expansion]. Rīga: LVU, 107 p. (in Latvian).

8. Jèdzienu interpretäcija bèrnu zimmejjumos. [Interpretation of the concept of children's drawings]. RPIVA Bērnu valodas pētījumu centra bērnu valodas datubāze. Retrieved October 23, 2011, from http://www.rpiva.Iv/index.php?mh=bvpc_jedzieni. (in Latvian).

9. Kalnača, A. (2005). Gramatizēšanās latviešu valodas sistēmā. [Grammaticalization in the System of Latvian]. In: Vārds un tā pētǐšanas aspekti. Rakstu krājums. 9. Liepāja: Liepājas Pedagoǵijas akadēmija, pp. 125 -131 (in Latvian).

10. Kārklin,̌̌, J. (1974). Praktikums mūsdienu latviešu literārās valodas sintaksē. I dala. Otrs papildināts izdevums. [Practicum on modern Latvian literary language syntax]. Rīga: P. Stučkas LVU redakcijas un izdevnieciibas dal̦a, 88 p. (in Latvian).

11. Kārklinš̌, J. (1976) Infinitīva sintaktiskās potences. Mācību līdzeklis sintaksē. [Potency of infinitive syntactic]. Rīga: P. Stučkas Latvijas Valsts universitāte, 96 p. (in Latvian).

12. LU Matemātikas un informātikas institūts. Lidzsvarots mūsdienu latviešu valodas tekstu korpuss. miljons-2.0 from www.korpuss.Iv. (in Latvian).

13. Maguire, M. J., Hirsh-Pasek, K. \& Golinkoff, R. M. (2006). A Unified Theory of Word Learning: Putting Verb Acquisition in Context. In: Hirsh-Pasek, K. \& Golinkoff, R. M. (eds.) Action Meets Word. How Children Learn Verbs (pp. 364-391). Oxford University Press.

14. Markus, D. (2003). Bērna valoda: no pirmā kliedziena lïdz pasakai. [Child language: From the first scream till fairytale]. Rìga: Rasa, 144 p. (in Latvian).

15. Markus, D. (2005). Bērns runā kultūras pasaulē. [Children talks in culture world]. Rīga: Rasa, 160 p. (in Latvian).

16. Mïlenbahs, K. (1898). Teikums. [Sentence]. Rīga: Pūcīšu Ģederta apgādība, 104 p. (in Latvian).

17. Paegle, Dz. (2003). Latviešu literārās valodas morfoloǵija. I dal̦a. [Morphology of the Latvian literary language]. Rīga: Zinātne, 240 p. (in Latvian).

18. Rūkse-Dravin,a, V. (1993). Latviešu meitene apgūst savu pirmo valodu. [Latvian girl acquires her first language]. Rīga: Dio Nordik, 112 p. (in Latvian).

19. Trask, R. L. (2000). The Dictionary of Historical and Comparative Linguistics. Edinburgh: Edinburgh University Press, $403 \mathrm{p}$.

20. Valdmanis, J. (1989). Teikums. [Sentence]. In: Ceplïtis, L., Rozenbergs, J. \& Valdmanis, J. Latviešu valodas sintakse. Rīga: Zvaigzne, pp. 13 -141 (in Latvian).

21. VPSV - Skujina V. (Ed.) (2007). Valodniecības pamatterminu skaidrojošā vārdnīca. Autoru kolektīvs: Bušs, O., Joma, D., Kalnača, A., Lokmane, I., Markus, D., Pūtele, I. \& Skujiña, V. [Linguistics glossary of key terms]. Rīga: LU Latviešu valodas institūts, 623 p. (in Latvian). 
Lecturer, researcher Mag. hum. Baiba Ivulāne

University of Latvia, Faculty of Humanities, Department of Latvian and General Linguistics

Visvalža iela 4a, Riga, Latvia

Riga Teacher Training and Educational Management Academy, Child Language Research Centre

Imantas 7. līnija 1, Riga, Latvia

Phone: 29398186

E-mail: baiba.ivulane@gmail.com 